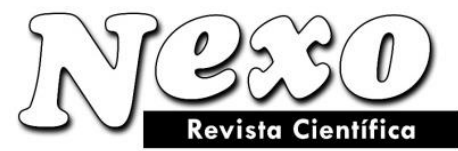

Vol. 34, No. 01, pp. 205-210/Marzo 2021
ISSN-E 1995-9516

Universidad Nacional de Ingeniería COPYRIGHT @ (UNI). TODOS LOS DERECHOS RESERVADOS

http://revistas.uni.edu.ni/index.php/Nexo https://doi.org/10.5377/nexo.v34i01.11298

\title{
Medieval clayware as a determiner of the ethnocultural composition of the population
}

\section{EI barro medieval como determinante de la composición etnocultural de la población}

\author{
Malvina Stanislavovna Kuptsova \\ Department of General and National History, Head of the Laboratory of Archeology and Ethnography, \\ Faculty of Philology and History, Yelabuga Institute, Kazan Federal University \\ malvina2711@bk.ru
}

(recibido/received: 02-December-2020; aceptado/accepted: 01-February-2021)

\begin{abstract}
This article examines the medieval utensils found on the territory of the medieval towns of Volga, Bulgaria. Statistical analysis, technical and technological analysis is carried out. Based on the analysis of material materials, ethnocultural groups are linked, their interaction, and their influence on the local Bulgarian population. Volga Bulgaria is a major state transformation on the territory of medieval Eastern Europe, which included a large number of immigrants, one of which, in this case, the Ugric component, will be considered in the article.
\end{abstract}

Keywords: Volga Bulgaria, Middle Ages, settlement, ceramics group, ornament, molding.

\section{RESUMEN}

Este artículo examina los utensilios medievales encontrados en el territorio de las ciudades medievales de Volga Bulgaria. Se realizan análisis estadístico, técnico y tecnológico. Basado en el análisis de materiales, los grupos etnoculturales están vinculados, su interacción e influencia en la población local Búlgara. Volga Bulgaria es un estado con gran transfomación en el territorio de la Europa oriental medieval, que incluía un gran número de inmigrantes, uno de los cuales, en este caso el componente Úgrico, se considerará en el artículo.

Palabras clave: Volga Bulgaria, Edad Media, asentamiento, grupo cerámico, ornamento, moldura.

\section{INTRODUCTION}


The 10th century, marked for the Volga region by the fall of the Khazar Kaganate, and the formation of a new centralized state of Volga Bulgaria on the territory of the Volga region, set in motion many peoples, including a large number of the Ugric-speaking population, who actively began to settle and contact the local Bulgarian population (Akhter, 2017; Lee, 2018). We see the process of interaction directly in the material culture itself when among the large abundance of good quality materials of Bulgarian artisans, there are objects not typical for local production. An example of this is the presence of a large percentage of medieval, or, as it is customary to call, "traditional" ceramics on Volga Bulgaria's monuments, which is a vivid indicator of ethnocultural processes throughout the Volga region (Cywa \& Wacnik, 2020). Often, ceramic material in settlements is practically the only dating material, and due to its high percentage of occurrence, it is the most extensive and complete material in terms of incoming information. It can create a solid foundation for the reconstruction of ancient societies' history, their development in time, the continuity of generations, cantaks among themselves, and the influence of ethnocultural groups on each other (Grömer et al., 2017; Laha et al., 2020).

\section{METHODS}

In the process of working on this article, general scientific methods of cognition were used: analysis, synthesis, induction, deduction. When writing the work, methods of cognition, traditional for historical science, were used, consisting of 3 stages: 1. Field (stratigraphic method); 2. Cameral laboratory (comparative typological method); 3. Cabinet (method of cross dating, problem-chronological, method of historical retrospection).

The stratigraphic method was carried out at the stage of field research of the Elabuga, Kirmensky, Staromashkinsky, Chalynsky settlements. This method consists of drawing up a stratigraphic plan of cultural strata of each of the settlements, establishing a chronological relationship between them, and fixing ceramic materials from each layer. At the laboratory-laboratory stage, a comparative typological method was made, which made it possible, based on the analysis of the material, to classify medieval dishes according to various ethnocultural groups (according to the class of T.A. Khlebnikova), which is based on the division into separate subgroups according to common characteristics: dough composition, dough shaping, ornamentation, etc. Based on the identified common features, a link was made to a specific ethnocultural group.

At the last office stage, a problem-chronological method was carried out, which made it possible to isolate a whole complex of narrow problems within the studied problem and trace their transformation. In particular, such problems include the presence of traditional "hybrid" dishes in the materials of the sites under consideration or even the absence of some groups of dishes.

\section{RESULTS AND DISCUSSION}

According to the materials of Volga Bulgaria's monuments, "traditional" dishes are distinguished, or dishes of the alien population (Table 1.). To study this category of tableware, materials from the following settlements were analyzed: Elabuga settlement (Elabuga, Republic of Tatarstan) is located on the right bank of the mouth of the Toima River, the right tributary of the Kama River. Located on the north-eastern side of the cape of the Kama root terrace at an altitude of 50-60 m; Kirmen settlement (Mamadyshsky district of the Republic of Tatarstan) is located on a high promontory on the left bank of the Kirmenka river, bounded from the west by a deep ravine.; Chalynskoe settlement (Rybno-Slobodskoy district, Republic of Tatarstan). Located on a high promontory of the left bedrock bank of the Shumbut River, the right tributary of the Kama, at an altitude of $24 \mathrm{~m}$, with a wide ravine from the south-east; Staromashkinskoye settlement "Kala", "Kalyush" (Chistopolsky district, Republic of Tatarstan) is located $17 \mathrm{~km}$ southeast of the city of 
Chistopol and $16 \mathrm{~km}$ south of the Kama river. $500 \mathrm{~m}$ north of the settlement is the village of. Old Romashkino.

In the work of T.A. Khlebnikova "Ceramics of the monuments of Volga Bulgaria" (Khlebnikova, 1984), work is underway to classify all medieval utensils found on the monuments of Volga Bulgaria; this work will be the main bias in the classification of ceramics on the sites under consideration. In total, T.A. Khlebnikova identifies 24 ethnocultural groups of medieval tableware, among which it is necessary to distinguish 6 main groups that are subject to analysis in this work.

The most numerous is the I "all-Bulgarian" group. The dishes are made of clay dough mixed with sand. Almost half of the dishes are burnished and well fired. Dishes are mostly brown (39.5\%), red (27\%), yellowred $(20.5 \%)$, significantly less brown $(8 \%)$, gray $(4.5 \%)$, and yellow $(0.5 \%)$ colors according to the Kirmen settlement. Earthenware is in a highly fragmented state, and therefore it is not easy to reconstruct its shape. However, almost all categories of vessels that are found in the Bulgarian settlements can be distinguished: pot-shaped, jug-shaped, bowl-shaped, cup-shaped, and dish-shaped. Linear motives prevail in the ornamentation of group I. Prints of a comb stamp, "commas" and wavy ornamentation along the neck, shoulder and body take a noticeable place. There are fragments with fluted ornament (Rasmussen et al., 2020).

This group of crockery is typical for most of the monuments of Volga Bulgaria. (see Table 1.) Only in the materials of the Yelabuga settlement do we see its scarcity (see Table 1); this is due to the fact that a large percentage of the population living on the territory of the Yelabuga settlement was Finno-Ugric, and only a small part of it was Bulgarian (most likely military nobility), since the settlement served as a military fortpost in the northeastern lands of Volga Bulgaria.

The next category of tableware is traditional:

The VII group of dishes, or the "postpetrogrom" dishes are molded, round-bottomed vessels with a crushed shell in the dough; T.A. Khlebnikova is considered as a promise that arose in the Sylven basin of the Upper Kama region as a result of mixing the traditions of making the Upper Kama Permian population and the former Trans-Ural-Ugric, with a large dominance of the latter. In quantitative terms, it prevails only in the Elabuga settlement materials (more than $60 \%$ of the total amount of ceramic material (Khuzin, 2008; Larreina et al., 2018; Rasmussen et al., 2020). There is no more than $10 \%$ of the total amount of ceramics (see Table 1).

This ceramic is characterized by rope-comb ornamentation along the neck and shoulder (more than $75 \%$ of dishes from the Staromashkinsky settlement), cutting along the rim's beveled edge (no more than 61\%). Pot-shaped and cup-shaped vessels are distinguished according to their forms;

The VIII group of ceramics among the pre-Mongolian group of ceramics was found only on the Staromashkinsky settlement territory. At the moment, there are a number of questions about the advisability of separating this tableware into a separate ethnocultural group, A.P. Smirnov assigns it to the VII group, only changed as a result of interaction with the local Bulgarian population. This group represents vessels of a denser sand dough with the addition of fine chamotte, cylindrical neck with carved ornamentation. In total, 61 fragments are represented in the Staromashkinsky settlement materials (absent in cultural layers, absent in structures). In percentage terms $-0.1 \%-0.2 \%$ of the total amount of ceramics is presented. These dishes are presented in cup and pot-shaped forms. A.T. Khlebnikova examines the formation of this group among the Kushnarenko dishes, only changed as a result of interaction among the local Bulgarian population; 
The 17th group of glassware represents the development of the 8th group of ceramics. In quantitative terms, 61 fragments account for $1-2 \%$ of the total amount of ceramics. The composition of the dough is without impurities visible to the eye, the shape of the vessel is also typical for VIII, when the lower part of the vessel is molded by hand, the upper part (rim and neck) are tweaked on a potter's wheel. Among the ornaments prevail single-row (wide) incident wave (which is also typical for group VIII) (Lee, 2018; Rasmussen et al., 2020). Stratigraphically refers to the upper layers of the materials of the Staromashkinsky settlement (XII - early XIII centuries); The 184 ceramics group is represented in only the Kirmen settlement materials in the amount of 184 fragments $(0.32 \%)$. Statically all originate from the upper horizon of the layer. The ceramics are presented in a highly fragmented form; it is rather difficult to reconstruct the vessels according to their shapes.

Table 1. Statistical data of "traditionally" ceramics for the settlements of Volga Bulgaria

\begin{tabular}{|c|c|c|c|c|c|c|}
\hline $\begin{array}{c}\text { Name of the } \\
\text { monument }\end{array}$ & I gr. (Obshebolgar) & $\begin{array}{c}\text { II or IX } \\
\text { (ceramics } \\
\text { of the } \\
\text { Saltovo- } \\
\text { Mayatsk } \\
\text { sources) }\end{array}$ & $\begin{array}{c}\text { VII («post- } \\
\text { petrogrom») }\end{array}$ & $\begin{array}{c}\text { VIIII } \\
\text { gr. }\end{array}$ & $\begin{array}{c}\text { XVII } \\
\text { gr. }\end{array}$ & $\begin{array}{c}\text { XVIII } \\
\text { gr. }\end{array}$ \\
\hline Elabuga settlement & $35 \%$ & - & $1 \%$ & - & - & $2 \%$ \\
\hline Kirmen settlement & $75,4 \%$ & $0,01 \%$ & $11 \%$ & - & $0,01 \%$ & $0,32 \%$ \\
\hline Chalynskoe settlement & $54 \%$ & $0,3 \%$ & $7,5 \%$ & - & - & - \\
\hline $\begin{array}{c}\text { Staromashkinskoe } \\
\text { settlement }\end{array}$ & $84 \%$ & $0,01 \%$ & $8 \%$ & - & - & - \\
\hline
\end{tabular}

\section{CONCLUSIONS}

At the moment, there are many debatable issues regarding the ethnocultural binding of each of the considered ethnocultural groups of dishes. Therefore, let us turn to the ethnocultural component of the VII group of ceramics, or "post-Petrogrom" ceramics (according to E.P. Kazakov). E.P. Kazakov distinguishes the carriers of this group into a separate archaeological culture with their appearance at the beginning of the 10 th century. EAT. Bers unites them into a separate Kalmak culture of the 4th-5th centuries. AD, chronologically, this version was supported by V.F. Gening, but attributed them to the Lomovat culture. T.A. Khlebnikova in her work "Ceramics of the monuments of Volga Bulgaria ..." dates them with the Ugric population of the 10th century, with the influence of the Upper Kama. We are inclined to identify the carriers of the VII group of ceramics with the Ugric population of the Cis-Urals.

Speaking about the ethnic belonging of the VIII group of ceramics, it should be noted that E.P. Kazakov (Kazakov, 1978), as a transitional type of comb-corded VII gr., Formed under the influence of Bulgarian pottery. He sees their certain similarity in the composition of the dough and in some ornamentation, particularly the arrangement of the ornament in certain parts of the dishes. Let's compare the data of the group of dishes according to the technological characteristic. The following will be: According to the composition of the dough, these groups are similar, only in some fragments of the dishes of group VIII can you find small chamotte. There is one definite difference in the shape of the vessels; the characteristic bevelling of the rim edge towards the inside of group VII on VIII is presented rounded. Ornamentation: for the VII group, only linear-comb ornamentation is characteristic when in the VIII it is diluted with a singlerow incident wave along the shoulder. As for the location of the ornament, VII - neck, VIII - shoulder and neck. Therefore, we consider it incorrect to identify the VIII group of ceramics with the VII for the reason: If the VIII group of ceramics is a modified group VII as a result of interaction with the local population, then it should have stood out in the materials of the Yelabuga settlement (Yelabuga settlement is the only monument in Volga Bulgaria where the percentage of VII relative to Bulgarian ceramics prevails - $60 \%$ of the total amount of ceramics), but there is none at all on this monument. The VIII group of ceramics should 
most likely be considered within the framework of interaction with the population of the "Dzhuketau okrug", when the presence of sand in the dough, the stage-by-stage manufacture of dishes and ornamentation were typical for this group of the population.

The XVII group of ceramics represents the development of the VIII so-called Ural sources. Certain features of similarity between groups VIII and XVII were noted by A.T. Khlebnikova, who pointed to their certain proximity - "the close texture of the dough ... the production of the 17th group of ceramics crossed the threshold of home production, probably it was designed for a certain circle of buyers who were dear to the traditions of making the 8th group of ceramics." Most likely, these are the population of the Lower Kama and Bashkir Urals.

Thus, based on the analysis of materials from Volga Bulgaria's monuments, it is possible to trace the ethnocultural processes taking place in the Volga region during the Middle Ages. An important role in this was played by the Ugric population who came to Volga Bulgaria's territory in the 10th century. The fact remains that the territory under consideration is a place where traditional ethnocultural technologies for making dishes were kept, and the partial separation of one group from another reflects the development of pottery and the formation of a single culture and ethnic group.

\section{ACKNOWLEDGEMENTS}

\section{The work is performed according to the Russian Government Program of Competitive Growth of Kazan Federal University.}

\section{REFERENCES}

Akhter, F. (2017). The Net of Nostalgia: Class, Culture, and Political Alienation and Nostalgia in Contemporary Latino and South Asian American Literature.

Cywa, K., \& Wacnik, A. (2020). First representative xylological data on the exploitation of wood by early medieval woodcrafters in the Polesia region, southwestern Belarus. Journal of Archaeological Science: Reports, 30, 102252.

Grömer, K., Russ-Popa, G., \& Saliari, K. (2017). Products of animal skin from Antiquity to the Medieval Period. Annalen des Naturhistorischen Museums in Wien. Serie A für Mineralogie und Petrographie, Geologie und Paläontologie, Anthropologie und Prähistorie, 119, 69-93.

Kazakov, E.P. (1978). Monuments of the Bulgarian time in the eastern regions of Tataria. Otv. Ed. OH. Khalikov. Moscow: Nauka, 45 p.

Khlebnikova, TA. (1984). Ceramics of the Monuments of the Volga Bulgaria. To the Question of the Ethnocultural Composition of the Population.

Khuzin, F.Sh. (2008). To the question of the so-called "post-Petrogrom" culture. Kama trade route: materials of the All-Russian. Scientific-practical. Conf. Elabuga, 11-22.

Laha, T., Gope, M., Datta, S., Masto, R. E., \& Balachandran, S. (2020). Oral bioaccessibility of potentially toxic elements (PTEs) and related health risk in urban playground soil from a medieval bell metal industrial town Khagra, India. Environmental Geochemistry and Health, 1-19. 
Larreina García, D., \& Quirós Castillo, J. A. (2018). The metallography of medieval agricultural and quotidian iron utensils from the rural settlement of Zaballa (Basque Country). Archaeometry, 60(6), 13061323.

Lee, W. C. (2018). Individuals' Accounts of Weight Loss, Maintenance, and Recidivism: A Phenomenological Study (Doctoral dissertation, Northcentral University).

Rasmussen, K. L., Milner, G. R., Delbey, T., Skytte, L., Søvsø, M., Callesen, F., \& Boldsen, J. L. (2020). Copper exposure in medieval and post-medieval Denmark and northern Germany: its relationship to residence location and social position. Heritage Science, 8(1), 1-22.

\section{SEMBLANCE OF THE AUTHORS}

Kuptsova Malvina Stanislavovna was born on November 27, 1991. In 2014, she graduated from the full course of study at the Faculty of History and Law at the Yelabuga Institute of the Kazan (Volga Region) Federal University with a degree in history and legal education. From 2016 to 2019 studied in full-time postgraduate study at the Federal State Autonomous Educational Institution of Higher Education "Yelabuga Institute of Kazan (Volga Region) Federal University" in the direction of 07.00.02. National history. At the moment he is working as a senior laboratory assistant at the Department of General and National History and head of the laboratory of archeology and ethnography at the Elabuga Institute of the Kazan (Volga Region) Federal University. 